\title{
The Economic Psychology of Creating and Venturing: A Comparative Behavioural Portrait of Artists and Entrepreneurs
}

Pia Arenius, Swee-Hoon Chuah, Bronwyn Coate, Robert Hoffmann

\begin{abstract}
There are anecdotal parallels between the productive activities, labour market conditions and policy importance of professional artists and entrepreneurs that suggest human capital similarities between them. We examine the psychological and behavioural characteristics associated with the pursuits of artistry and entrepreneurship. We conducted a laboratory study with 216 artists, entrepreneurs and professional workers performing a series of psychometric tasks to enable their direct comparison. We find both artists and entrepreneurs exhibit higher risk tolerance, openness to experience and intrinsic motivation compared to the control group of professional workers. Artists score higher in creativity and emotionality compared to entrepreneurs, and entrepreneurs in self-efficacy and extraversion compared to artists.
\end{abstract}

Keywords Artists, Entrepreneurs, Arts Entrepreneurship, Creativity, Risk Attitude, Personality

JEL Classifications: D91, L26, Z11 
At first blush the artist and the entrepreneur share features that differentiate both from other types of professional (Daum 2005; Poorsoltan 2012). Anecdotally, much of artistic and entrepreneurial work is non-routine and intuitive where value creation is an expression of individuality. For both, that value is associated with subjectivity and risky prospects. Both require funding to market their products. Both are seen to engage in meritorious activity subject to significant government support. Both face a professional paradox where individualistic vision is often confronted by the need to appeal to public or market funding. Even if some artists may not wish to be characterised as such, the habits associated with an 'entrepreneurial mindset' have been identified as increasing the chances of success in the pursuit of an artistic career (Eikhof and Haunschild 2006).

Given the growing interest in the intersection of art and entrepreneurship, this paper brings artists and entrepreneurs together in a single study to measure their psychological attributes. We examine to what extent artists and entrepreneurs share psychological traits and behaviour tendencies that differentiate them from other professionals. Our laboratory study comprised 216 otherwise comparable artists, entrepreneurs and professional workers. They performed a combination of behavioural tasks and psychometric tests to systematically capture psychological factors associated with artists and entrepreneurs.

Our key contribution is to measure eight such characteristics in artists, entrepreneurs and professionals within a single study using the same established psychometric tests and behavioural economics tasks affording a valid and reliable comparison. To our knowledge our study is the first study to do so. Previous work has separately compared either artists or entrepreneurs to different baseline groups. These studies do not provide reliable support for the overlapping and distinguishing features of artists and entrepreneurs because such support would necessitate comparing across different studies. Such cross-study comparisons are generally fraught with problems including different measurement scales, different baseline groups and a variety of different confounding influences (such as different environmental influences on participants, different elicitation methods or experimenter effects) that affect these studies differently. Our single study uses the same measures, a common baseline group and identical controls for other potential influences, allowing a valid and reliable comparison across the groups.

Understanding the psychological similarities between artists and entrepreneurs is important given the practical realities that propel many artists towards entrepreneurism. With precarious employment and dwindling public funding to support the arts, artists need to embrace entrepreneurism.

In section 2 we look at the field of arts entrepreneurship to which we contribute. In section 3 we examine each of the psychological characteristics that we hypothesise to distinguish both artists and entrepreneurs from other occupations. In each subsection we introduce the relevant concept and discuss previous literature that motivates our resulting hypotheses. Section 4 describes the study design and data collection and section 5 presents our results. Section 6 concludes with a summary along with the implications and limitations of our work.

\section{Arts Entrepreneurship}


The intersection of art, entrepreneurship and the economy has given rise to a niche field of scholarship dedicated to arts entrepreneurship. The ability of artists to successfully navigate the challenges of precarity and exploit opportunities for entrepreneurism matter in setting the course of their career trajectories. Given the importance of entrepreneurial self-interest to assist artists gain a foothold in the insecure labour markets that characterise the cultural sector, Coulson (2012) notes that "being proactive, in other words not waiting for work to come, is one of the means by which (artists) entrepreneurs can improve their chances of success." Woronkowicz and Noonan (2017) find that living in a city with a high saturation of artistic occupations is associated with a rise in self-employment status among artists. Consistent with this creative industry development and policy initiatives in many countries also reflect the importance of entrepreneurism within the cultural sector (Eikhof and Haunschild 2006).

Given the existence of these forces and high levels of competition to be an artist, the capacity of entrepreneurism is increasingly recognised as a necessary condition for artists' survival. A substantial literature in arts entrepreneurship is devoted to the role of entrepreneurship and business competency skills training for art students (Bridgstock 2013). Factors such as training and access to networks have been identified as ways to advance artists' entrepreneurism. However, further enhancement to the entrepreneurship training for art students could potentially be aided by positive psychology pedagogy (Carr 2011) to develop key behavioural competencies. Identifying the behavioural and psychological competencies associated with entrepreneurship may inform artepreneur training and self-development programs.

\section{$3 \quad$ Psychological characteristics of artists and entrepreneurs}

How, and to what extent, are artists and entrepreneurs similar and distinct from other groups? We focus on the psychological factors identified in separate empirical literatures examining the psychology of artists (Rank 1932; Cross et al. 1967; Csikszentmihalyi and Getzels 1973; Götz and Götz 1979; Kemp 1996; Feist 1999) and entrepreneurs (McClelland 1987; Rotter 1966; Gartner 1989; Timmons 1989; Shaver and Scott 1991; Zhao and Seibert 2006; Baum et al. 2014). We use these studies to identify psychological characteristics that distinguish artists and entrepreneurs from others resulting in eight hypotheses shown in Table 1. We now examine these in turn.

[Table 1 about here]

\subsection{Personality}

Personality is a system of relatively stable psychological predispositions that explain a person's typical emotional, cognitive and behavioural patterns. Several comprehensive, multi-factor inventories exist that identify fundamental factors under which all personality attributes are said to be subsumed. Previous studies evidence that artists and entrepreneurs are characterised by particular personality traits. For instance, artists tend to be more psychotic and introverted but also more adventurous and radical (Drevdahl and Cattell 1958; Cross et al. 1967; Götz and Götz 1979; Kemp 1996). Personality helps explain the uniqueness of an individual and has been linked to creativity (Barron 1955). Despite equivocal empirical findings the meta-study of Feist (1998) concludes that artists tend to be relatively more aggressive, cold, egocentric, impulsive and open. Abuhamdeh and Csikszentmihalyi (2014) caution against a single artist personality as the typical profile varies 
by the type of art practice, between styles within a given practice and also over historical periods.

Entrepreneurship research has focused on personality traits associated with two main aspects of entrepreneurial activity: becoming an entrepreneur and succeeding at running a new business. Again the personality difference patterns are not consistent across studies (Pekkala Kerr et al. 2018) and the effect sizes are relatively small (Rauch 2014). Recent meta-analyses nevertheless report that conscientiousness, openness to experience, emotionality and extraversion are each positively related to intentions to become an entrepreneur (Zhao and Seibert 2006).

\subsection{Intrinsic motivation}

Intrinsic motivation exists when an action is performed not towards some extrinsic objective but for its own reward. Intrinsically motivated behaviours are often self-actualising or involve pursuit of a higher purpose accompanied by deep immersion or flow (Ryan and Deci 2000). In the field of art this can involve exercising mastery through self-development. It has been theorised that artists derive 'psychic income' from following their passion and creative impulse that is distinct from the financial reward (Abbing 2002). Entrepreneurs are also motivated by passion. For instance, Carland et al. (1995) describe the pursuit of selfactualisation through entrepreneurial activities. Similarly, Cardon and Kirk (2015) find that passion is the key element for the pursuit of entrepreneurial opportunities and aids persistence under adverse conditions.

Intrinsic motivation has been linked to task orientation (Nicholls 1984), participation in an activity in order to acquire the skills and knowledge and to perform as well as possible. Being highly task orientated is associated with a sense of personal improvement, where trying hard and learning new things instill feelings of success and competence.

\subsection{Risk preference}

Risk preference reflects a person's willingness to trade off larger uncertain gains with smaller but safer ones. A person's risk preference may vary situationally (through emotional states), over time (through learning) and according to the context of the decision (Dohmen et al. 2011). For instance, creative risks expressed in artists' practice or in entrepreneurs' development of new products may be perceived quite differently from other risky decision making.

Art creation ordinarily involves the risk in challenging the status quo with uncertain acceptance in the presence of strong competition. The appraisal of an artist's work by both peers and the market involves subjective judgment that is inherently hard to predict. Beyond practice, artists display risk-taking behaviour in choosing a career where earnings are low and uncertain. For instance, the preference towards multiple job holding over the security of more regular work has been suggested by some to indicate that artists are risk taking (Throsby and Zednik 2011).

Consideration of risk is an everyday task for entrepreneurs. In a meta-analysis Stewart and Roth (2001) found that the risk propensity of entrepreneurs is greater than that of managers. Carland et al. (1995) find that entrepreneurs whose goals relate to profit and growth have higher risk preferences compared to those who are more family oriented. Moreover, simply 
being an entrepreneur and running a business has been found to change risk preferences (Brockhaus 1980).

\subsection{Creativity}

Creativity is the ability to generate different ideas and solutions to a problem through divergent thinking, the spontaneous exploration of multiple alternatives (McCrae 1987). Previous literature has established both artists and entrepreneurs as relatively creative (Daum 2005; Heunks 1998) where satisfaction resides in creating something new (Cowen and Tabarrok 2000), and where the creative process is a source of self actualisation (Maslow 1943).

Art and cultural products are prized for their uniqueness and as an expression of individuality and creativity. Studies have found that artists demonstrate high levels of discovery orientation and originality in the development of creative products (Csikszentmihalyi and Getzels 1973). Reviewing the literature, Collins and Amabile (1999) conclude that high levels of creativity are associated with personal involvement and connection to work which become motivations in themselves.

Similarly, creativity is seen as important to entrepreneurship, linked to ideation that is "the lifeblood of entrepreneurship" (Ward 2004). For Amabile (1997), entrepreneurial creativity is "the generation and implementation of novel, appropriate ideas to establish a new venture" (p. 20).

\subsection{Social value orientation}

A person's social value orientation (SVO) represents a preference for a particular distribution of outcomes to themselves and to others (Messick and McClintock 1968). A preference for the former is known as a 'pro-self' orientation and the preference for the latter a 'pro-social' one. Pro-socials make choices which try to minimise the difference between their own and others' outcomes (equality) as well as maximise everyone's joint outcomes (cooperation). SVO which has been found to be predictive of behaviours such as cooperation, helping and self-sacrifice (Pletzer et al. 2018; McClintock and Allison 1989).

Although artists have been typified as selfish (Harris 2011) and competitive (Poorsoltan 2012), the arts have been used as a catalyst for pro-sociality and cooperation between people (Van de Vyver and Abrams 2018), evidenced for instance by environmentally-motivated art. Entrepreneurs too are viewed by some as selfish, working to increase their wealth without considering the effects of their activities on society (Baumol 1996). Yet there are those recognised as social entrepreneurs, driven by their desire to address need in communities (Germak and Robinson 2014). It has also been found that pro-sociality strengthens the association between intrinsic motivation and creativity, both characteristics associated with artists and entrepreneurs (Grant and Berry 2011).

\subsection{Self-efficacy}

Self-efficacy is an individual's belief in their capability to produce desired outcomes (Bandura 1986). Drevdahl and Cattell (1958) found artists to be more self-sufficient and selfconfident. Links between high standards, such as looking for perfection in their work, and affective reactions such as anxiety and stress depend on certain moderating factors. 
According to Bandura (1986), one is perceived self-efficacy (or personal control). Similarly Mor et al. (1995) find evidence of high personal standards in the form of self-orientated perfection in performing artists. Kenny et al. (2004) find an inverse relationship between selfefficacy in opera chorus performers and performance anxiety.

In the entrepreneurship literature self-efficacy has been associated with opportunity recognition and risk-taking (Krueger and Dickson 1994). It is pivotal to self-employment intentions (Scherer et al. 1989) and a key element in venture creation (Koellinger et al. 2007). Recent studies have found that self-efficacy is positively related to new firm start-up (Townsend et al. 2010) and firm persistence (Cardon and Kirk 2015), and negatively related to disengagement from the start-up process (Khan et al. 2014).

\subsection{Overconfidence}

Overconfidence means a person's judgement of their own knowledge, accuracy or ability is biased in a self-serving manner. Overconfidence is a potential explanation for risky decision making (Campbell et al. 2004). For instance, many creative industries are winner-take-all markets where the lure of fame and fortune attracts many more 'contestants' than can make a living (Frank and Cook 1996). Yet even without expectation of fame, more typical artists can underestimate competition (Feist, 1989). An artist's own innate sense of ability may drive an unrealistic decision to pursue an artistic career because prospects are hard to gauge objectively.

Overconfidence has also been studied in the context of entrepreneurs as a bias explaining why entrepreneurs start businesses even when the odds of success are low. For example, Åstebro et al. (2007) find that entrepreneurs as a group score higher both on optimism and overestimation compared to a group of ordinary citizens. In a later literature review, Åstebro et al. (2014) and Pekkala Kerr et al. (2018) conclude that overconfidence can help explain entrepreneurial entry.

\subsection{Inattention, hyperactivity and impulsivity}

People in different occupations manifest different levels of symptoms associated with Attention-Deficit/Hyperactivity Disorder (ADHD). It has been speculated that artists including Leonardo Da Vinci, Vincent Van Gogh and Pablo Picasso had ADHD. Research has found that artists exhibit higher impulsiveness (Feist 1989). Honos-Webb (2010) argued that distractibility, poor impulse control and emotional sensitivity, which are symptomatic of ADHD, are linked to creativity, energy and intuition, all of which are associated with artistry.

The press has called ADHD the "entrepreneurs' superpower" (Archer 2014). There is evidence suggesting the prevalence of ADHD is higher among the self employed compared to the general population (Verheul et al. 2015). In a study by Lasky et al. (2016), young adults with ADHD expressed preference for highly stimulating work environments characterised by unpredictability, such as the pursuit of both art and entrepreneurship. Early findings show how ADHD symptoms provide advantages in creativity, intention, action, performance and productivity in the process of entrepreneurship (Wiklund et al. 2018)., ADHD has also been associated with increased entrepreneurial intentions (Verheul et al. 2015; Lerner et al. 2019). 
We use a mix of established psychometric tests and behavioural economics tasks to capture the distinct psychological characteristics of artists and entrepreneurs based on the literature. As a complement to questionnaire-based psychometric instruments, behavioural economics tasks allow the direct observation of behaviour to measure various individual differences. These newer measures also allow convergent validation of previous findings. We collected these behavioural measures under incentive compatibility, i.e. when decisions of participants are associated with performance-related rewards in order to reduce response bias and elicit true behaviour (rather than intentions).

\subsection{Participants}

We recruited 216 participants from three occupational groups: artists, entrepreneurs and professional workers in metropolitan Australia. Recruitment strategies were targeted to attract each of these occupational groups. Participation was remunerated including the performancerelated component for the behavioural economics tasks.

Participating artists were not restricted to any specific creative practice, although the majority were visual and performing artists. To be included they needed to earn some share of their overall income from their creative practice. Given the well-established precariousness of creative incomes (Throsby and Zednik 2011) we did not specify a lower bound with respect to the level of creative income. We contacted artists through organisations, social media, emails and posters and online forums frequented by artists. Posters were physically placed around different studio and rehearsal spaces located in proximity of the metropolitan study location.

For the entrepreneurs we invited founders of start-up companies, both young and mature, as well as nascent entrepreneurs. These individuals were identified through their associations with local start-up groups as well as business incubators. To verify eligibility the entrepreneurs who expressed an interest completed a screening questionnaire to verify they were currently the owner-manager of an existing business. We also asked when they founded the businesses and to provide its website which we verified. The screening survey was also used to verify that any nascent entrepreneurs were actively working towards the launch of a new venture and would be an owner of the new business. We also verified the existence of any previous entrepreneurial experience in starting and exiting a business. Finally, professional workers were recruited from large organisations within the education and banking sectors.

Participants were assigned to an occupational group based on the recruitment stages described above, i.e. into the group they identified with. While self-selection for group assignment is well established in research (see Schubert and Otten 2002), some overlap may exist between groups. To uncover the extent of any overlap the online questionnaire included questions to elicit information concerning artistic and/or entrepreneurial experience and type of artistic and/or entrepreneurial practice across the three groups. Some 37\% of the artists indicated previous entrepreneurial experience of starting and running a small business. This is expected given the contract-like nature of artistic work that results in relatively high levels of self-employment. Of those within the entrepreneur group none identified as having any current or previous artistic practice experience of any type. 
A description of the participants across the three groups is provided in table 2 . The average age of was 36 years and $51 \%$ were female. Some, $79 \%$ had at least a bachelor's degree. For $84 \%$ English was the main language spoken at home. ANOVA and $\chi 2-$ tests show no significant differences between the demographic characteristics of the three groups in terms of age $(\mathrm{F}(2,213)=2.10, \mathrm{p}=0.125)$ and education attainment $(\chi 2(8, \mathrm{~N}=216)=6.36, \mathrm{p}=$ $0.607)$. However, the gender composition differed significantly $(\chi 2(4, \mathrm{~N}=214)=23.58, \mathrm{p}=$ $0.000)$ with a higher proportion of females in the professional $(62 \%)$ and artist $(58 \%)$ groups compared to the entrepreneurs (34\%). English native language status also differed $\left(\chi^{2}(2\right.$, $\mathrm{N}=216)=5.41, \mathrm{p}=0.067)$ with a higher proportion of English native speakers in the artist $(90.3 \%)$ group, compared to entrepreneurs $(80 \%)$ and professional workers $(77 \%)$. As a result, gender and English native language status are among the variables we controlled in regression analysis.

[Table 2 about here]

\subsection{Sessions}

We conducted 19 experimental sessions with between 6 and 20 participants in an experimental laboratory with partitioned computer terminals. After signing consent forms participants completed a sequence of tasks at the same time. These included a computerbased risk preference task. A creativity task was conducted in two parts where instructions were read out loud and participants recorded responses on sheets of paper.

The final task was an online questionnaire. The risk and creativity tasks were designed to elicit participant behaviour using financial incentives based on performance, whereas the questionnaire contained questions to assess their personality and SVO as well as levels of intrinsic motivation, self-efficacy, ADHD and overconfidence. It also contained demographic questions tailored to the various groups to elicit artist and entrepreneur types and experience.

Experimental sessions typically lasted 90 minutes (including two other behavioural tasks not reported here). They were paid either in cash or bank transfer between one and two weeks after the session. On average, participants received AUD 41.60 (approximately USD 28), with AUD 15.60 (approximately USD 10) of that for the two (risk and creativity) incentivised tasks reported here.

\section{$5 \quad$ Results}

Our central aim is to compare psychological and behavioural characteristics of artists, entrepreneurs and a comparable group of professional workers. The first column of table 3 lists the measures. Average scores for each of the three groups are shown in columns 2-4. This is followed by the results of ANOVA-tests for differences between the three groups. In the last three columns we report Scheffé post-hoc test results for differences between any two of the three groups compared to each other. Table 4 displays Pearson correlations between all the measures.

[Tables 3 and 4 about here]

Next, we use ordinary least squares and logit regressions with robust errors to test whether our univariate results are robust to the addition of control variables (age, gender, education and English native language status). For each psychological measure we estimate three 
separate specifications of the basic model, each with one of the three occupational groups as the benchmark and the other two represented by dummies. The significance of an occupational dummy indicates a difference of the group concerned to the benchmark group. In this manner we can directly compare each of the three occupational groups to every other. The regression results are reported in tables 5 and 6 . We use the term 'marginally significant' for $\mathrm{p}$-values $\geq 0.05$ but $<0.1$, and 'significant' when $<0.05$.

[Tables 5 and 6 about here]

Our summary results are presented in figure 1. The top panel shows average participant scores for each group for the HEXACO personality instrument. In the middle panel, normalised average scores for the other measures are given by group, i.e. expressed as a proportion of the average for all participants. The bottom panel displays the proportion of participants in each group who were classified into the three SVO types.

[Figure 1 about here]

\subsection{Personality}

We used the 60-item HEXACO Personality Inventory (Ashton and Lee 2009) to assess personality on the six major dimensions: honesty-humility (HEX-H), emotionality (HEX-E), extraversion (HEX-X), agreeableness (HEX-A), conscientiousness (HEX-C) and openness to experience (HEX-O). Figure 1 shows the average scores for these six dimensions for each group.

ANOVA-tests revealed no differences between any of the groups in terms of honestyhumility, agreeableness and conscientiousness. However, they differed significantly in terms of openness to experience, with artists ahead of entrepreneurs and followed by professionals. Each group was significantly different from both other groups in all our analyses. For emotionality, there were significant differences among the three groups with artists scoring significantly higher than entrepreneurs. The three groups differed significantly in extraversion as well, with entrepreneurs and professionals (marginally) both significantly more extravert than artists in the post-hoc analysis.

These differences are generally robust controlling for demographic factors in the regressions (table 5). The results for personality (models 1-6) show that in terms of emotionality (model 2), artists' scores are significantly higher than those of entrepreneurs, but neither group differs from professionals. For extraversion, the three specifications of model 3 attest to significant differences between each of the three occupational groups. Entrepreneurs are significantly more extravert than both professionals and artists, and artists are less extravert than both the other groups. Similarly, every group differs significantly from every other in terms of openness to experience (model 6). Artists are more open than both entrepreneurs and professionals; the latter are less open than both the other groups. There are no significant differences between any of the three occupational groups for honesty-humility, agreeableness and conscientiousness. The demographic controls for education and English are insignificant throughout. Age and gender are significant predictors for some of the personality dimensions.

\subsection{Intrinsic motivation}


Intrinsic motivation can manifest in different ways. In this study we focus on learning goal orientation, an individual's motivation to self-develop through the acquisition and mastery of new competences. We used a 4-item learning goal orientation instrument (VandeWalle 1997) to measure intrinsic motivation (INTMOT), with high reliability (Cronbach $\alpha=0.83$ ). The scale includes items such as 'I often look for opportunities to develop new skills and knowledge.'

Results showed that groups differed significantly in terms of their INTMOT, driven by a significant difference between artists and professional workers in the post-hoc analysis, associated with the highest and lowest average scores respectively. The regressions (table 6, model 5) show that professional workers are significantly less intrinsically motivated than artists and entrepreneurs (marginally), who do not differ from one another.

\subsection{Risk preference}

We measured risk preferences using two instruments: a behavioural task and a single selfreport questionnaire item. To measure risk behaviour we used an adaptation of the Balloon Analogue Risk Task (BART, Lejuez et al. 2002). Participants wearing headphones were asked to enter the number of desired inflations of an animated red balloon with and sound effects according to inflation level and outcome (air intake followed by pop or cash register sound). Participants were given 100 points and told that each inflation attracted an additional point unless a balloon explosion was triggered by a random explosion point between 0 and 127 inflations resulting in the loss of all points. This task was repeated 10 times. Earnings were paid out at AUD 1 (approximately USD 0.70) per point. The measure RISK-OB is the average number of inflations over the 10 balloons played. Secondly, we asked participants to self-report their general willingness to take risks (RISK-SR) between 0 ( $=$ not at all prepared to take risks) and 10 (=fully prepared to take risks). This measure was shown by Dohmen et al. (2011) to be highly predictive of risk behaviours in different everyday work and leisure contexts.

The risk evidence is mixed. Firstly, for RISK-SR, artists reported higher average responses than professionals with entrepreneurs the highest of all. The group difference was significant overall. The pairwise differences were significant between professionals and each of the other two groups. The regressions confirm these findings (table 6, model 1). Artists and entrepreneurs do not differ, but both groups self-report significantly higher risk tolerance than professionals. Hence findings on the self-report measure confirm our hypothesis. The RISKOB results reveal that entrepreneurs on average asked for more inflations than the other two groups, suggesting greater risk tolerance. However, the group difference in RISK-OB is only marginally significant, driven by a marginal difference between artists and entrepreneurs found in the post-hoc analysis. However, the regression analysis (table 6, model 2) shows no significant differences between the occupational groups. The demographic control for age is the only significant explanator of observed risk behaviour. Hence on the basis of observed behaviour artists in particular do not prove to be more risk taking than professional workers.

These two different risk measures suggest that while both artists and entrepreneurs report themselves to be relatively more risk loving (RISK-SR), this is not conclusively reflected in their actual decisions (RISK-OB). The disagreement between self-reported and overt risk taking may be attributed to different reasons, including the standard attitude-behaviour inconsistency issue and inconsistencies in risk attitude measurement (Pedroni et al. 2017). Our data do not generate an explanation which we leave for further research. 


\subsection{Creativity}

We elicited creativity using two divergent thinking tasks adapted from the Torrance Tests of Creative Thinking (Plucker and Renzulli 1999). In the first part, participants were asked to draw as many conceptually different objects which incorporate a given geometric form (a horizontal pair of circles) as possible. In the second, participants were shown a picture of an everyday object (a pencil) and asked to list as many conceptually different unusual uses for it as possible. Each of the two parts lasted two minutes and participants were told they would be paid AUD 0.50 (approximately USD 0.35 ) for each unique and valid response they provide within this time. We measured the creativity (CREAT) of each participant as the total of these unique responses. CREAT differed significantly between the three groups, with artists having the highest scores followed by entrepreneurs and professionals. In the post-hoc tests, artists' creativity was significantly greater than the other two groups, which did not differ. These results are confirmed by regressions (table 6, model 3). Among the demographic control variables only English is a significant influence on creativity.

\subsection{Social value orientation}

To measure SVO we followed Van Lange et al. (2007) and presented participants with a series of three different allocations of points between themselves and an anonymous other. The three different allocations were neutrally labelled but were pro-social, individualistic and competitive in nature. Participants chose their preferred allocations nine times, each time with different order and points. We categorised participants as pro-social (SVO-P), individualistic (SVO-I) or competitive (SVO-C) if six or more of their nine choices were consistent with that orientation (McClintock and Allison 1989). Those without six or more consistent choices were not categorised.

Contrary to our expectations, there was considerable variation in the SVO classifications of our participants across the three occupational groups. A greater proportion of artists were pro-social (84\%) compared to entrepreneurs $(62 \%)$ and professional workers $(75 \%)$. A greater proportion of entrepreneurs were individualistic (22\%) compared to the other two groups (17\% of professional workers and $4 \%$ of artists). When examining each SVO type separately, the proportions of SVO-I and SVO-P (but not SVO-C) were different between the groups (table 3). The post-hoc analyses confirmed significant differences between artists and entrepreneurs in all three (marginally for SVO-C). The only other post-hoc difference was the smaller percentage of individualistic artists compared to professional workers.

In the regressions (table 5, models 7-8) we do not model SVO-C due to the small proportion of participants classified into this type. Artists are significantly less likely to be individualistic than both other groups, which do not differ in this regard. Artists are also significantly more pro-social than entrepreneurs. Professionals do not significantly differ from either group in terms of pro-sociality. Gender is the only demographic that significantly explains SVO.

\subsection{Self-efficacy}

We adopted the general resilience self-efficacy measure proposed by Bandura (2006) as a global construct generalised over several domains with an eight-item scale (SELFE, Cronbach $\alpha=0.93$ ). Data collected from this reflects participants' general belief in their 
ability to keep their spirit up during times of hardship, to bounce back from failure and try again, and get rid of self-doubt.

SELFE differed significantly by group with entrepreneurs scoring higher than the other two groups who had similar levels. The difference of entrepreneurs to each of the other groups is confirmed by post-hoc analysis. Regression results confirm significantly greater self-efficacy in entrepreneurs compared to both other groups, who do not differ from one another (table 7 , model 4).

\subsection{Overconfidence}

Overconfidence manifests in different forms. We capture overconfidence as participants viewing themselves as more able compared to the average. We followed the approach taken Yang and Zhu (2016) and asked our participants: "Out of every 10 participants doing the tasks in this experiment, how many do you think will end up making more money from the tasks than you?" Each participant's response is then subtracted from ten to calculate their level of overconfidence (OVERC). A "neutral" participant who did not think they were either better or worse than average would score 5 .

We did not find significant differences between the groups in terms of OVERC either in ANOVA) or post-hoc analysis. However, a t-test finds that entrepreneurs are marginally more overconfident than artists. Regression analysis (table 6, model 7) fails to uncover any significant differences in overconfidence between any of the three groups. Again, gender alone achieves significance as an explanator.

\subsection{Inattention, hyperactivity and impulsivity}

We adopted the six screening questions of the Adult ADHD Self-Report Scale (ASRS-v1.1) (Kessler et al. 2005) to measure inattention, hyperactivity and impulsivity (ADHD). The scale includes items such as 'How often do you have difficulty getting things in order when you have to do a task that requires organisation?' and 'How often do you have problems remembering appointments or obligations?'. The measure we derived had somewhat poor reliability (Cronbach $\alpha=0.52$ ).

For this measure there were significant differences in ADHD scores by group driven by higher scores for artists compared to professionals. These findings are borne out in the regression analysis (table 5, model 6), where artists score significantly higher than professionals with no other significant group differences in evidence. The demographic control for age is also a significant factor.

\section{Conclusion}

We examined whether artists and entrepreneurs as individuals share certain psychological characteristics suggested in existing literature, and whether they differ in these compared to a baseline of professional workers. As occupational groups, artists and entrepreneurs have been proposed to be similar, but at present, limited and equivocal empirical evidence exists. Our study is the first to allow a valid comparison between these three groups by measuring participants with the same behavioural and psychometric instruments within one study. 
We find that artists and entrepreneurs share three key features: Both exhibit higher selfreported risk preference, are more open to experience and have greater intrinsic motivation compared to the control group. Artists score higher in emotionality, openness to experience and creativity compared to entrepreneurs, and are significantly more pro-social compared to entrepreneurs. Entrepreneurs, on the other hand, score higher in extraversion and selfefficacy than artists, and have a higher proportion of individualists.

Our study makes two important contributions. First, we contribute to the continued crossfertilisation of insights into the growing field of arts entrepreneurship. Second, our study can inform both practice and policy in both arts and entrepreneurship. A better understanding of the psychological and behavioural characteristics of artists and entrepreneurs can assist in formulating more effective social and economic welfare policies targeting artists and entrepreneurs. For instance, making artists more entrepreneurial may aid creative industry development but necessitates understanding how artists and entrepreneurs are similar or different. Also, the instinctive suspicion many artists harbour regarding entrepreneurship education (Beckman 2007) may be addressed with an appeal to the underlying similarities of both areas. Such education may result in artistic entrepreneurship that enhances the career success of artists.

Our study has several limitations. First, both artists and entrepreneurs are heterogeneous groups with large within-group differences. The characteristics we measure are likely to depend on the type of art (performing, visual or literary) or entrepreneurship (novice, opportunistic or habitual) a person is engaged in. Second, as mentioned at the outset, it is important to recognise the role of other human capital (training) as well as external factors (institutions, serendipity and opportunity) in shaping the behaviour of artists and entrepreneurs regardless of their psychological profile. For example, Zhou and Shalley (2003) emphasised the need to identify and examine contextual factors that facilitate or inhibit creativity.

Further, all three occupational groups presented us with significant recruitment challenges which generated a somewhat uneven sample size for each. We cannot entirely rule out effects of our sampling on the results we report. On the other hand, the observed demographics of our participants across the three groups were similar in age and educational attainment, with differences in gender and native language controlled for in the regression analyses. Nevertheless, future work should explore strategies to effectively secure larger and more balanced samples and also consider within groups analysis to distinguish, for instance between different types of artists and different types of entrepreneurs.

Our work is also affected by the general issues associated with psychometric measures that have been discussed in detail elsewhere. The same is true for abstract experimental tasks performed for financial reward that do not invoke contextual thinking typically associated with everyday human cognition. For example, the measurement of risk preference depends both on the type and abstractness of the measure (Pedroni et al. 2017). The measures we used, while established, were not developed for our specific context. Future work using tools designed or adapted to artists and entrepreneurs seems warranted.

It is also important to recognise the exploratory nature of this study. While the psychological characteristics we cover are extensive, they are clearly not exhaustive due to budgetary, time and participant fatigue constraints. We included the characteristics that anecdotal evidence and previous literature suggested as most relevant for both artists and entrepreneurs. Further, 
all the characteristics we considered have alternative measures that further work could examine for greater robustness. In a similar respect, our classification of participants as artists, entrepreneurs and professional workers was blunt, based on recruitment by group membership, self-report and self-selection. Overall, our study was designed for breadth rather than depth to serve as a basis for more fine-grained future work which we hope other researchers will continue. 


\section{References}

Abbing, H. (2002). Why are artists poor? The exceptional economy of the arts. Amsterdam University Press.

https://doi.org/10.5117/9789053565650

Abuhamdeh, S. and Csikszentmihalyi, M. (2014). The artistic personality: A systems perspective. In The Systems Model of Creativity, pp. 227-237. Springer.

https://doi.org/10.1037/10692-003

Amabile, T.M. (1985). Motivation and creativity: Effects of motivational orientation on creative writers. Journal of Personality and Social Psychology, 48(2), 393- 399.

https://doi.org/10.1037/0022-3514.48.2.393

Amabile. T. (1997). Entrepreneurial Creativity Through Motivational Synergy. Journal of Creative Behavior. 31(1), 18-26.

https://doi.org/10.1002/j.2162-6057.1997.tb00778.x

Ashton, M. C. and Lee, K. (2009). The HEXACO-60A short measure of the major dimensions of personality. Journal of Personality Assessment, 91, 340-345.

https://doi.org/10.1080/00223890902935878

Åstebro, T., A. J. Scott, and Gordon, K.A. (2007) Inventor perseverance after being told to quit: The role of cognitive biases. Journal of Behavioral Decision Making. 20(3), 253-272. https://doi.org/10.2139/ssrn.925223

Åstebro, T., Herz, H., Nanda, R., and Weber, R.A. (2014). Seeking the roots of entrepreneurship: Insights from Behavioral Economics. Journal of Economic Perspectives, 28(3), 49-70.

https://doi.org/10.2139/ssrn.2635874

Bandura, A. (1986). The explanatory and predictive scope of self-efficacy theory. Journal of Social and Clinical Psychology, 4(3), 359-373.

https://doi.org/10.1521/jscp.1986.4.3.359

Bandura, A. (2006). Guide for constructing self-efficacy scales. In Pajares, F., Urdan, T. (eds.) Self-efficacy Beliefs of Adolescents, pp.307-337.

Baum, J.R., Frese, M. and Baron, R.A. (2014). Born to be an entrepreneur? Revisiting the personality approach to entrepreneurship. In The psychology of entrepreneurship, pp. 73-98. Psychology Press.

Barron, F., (1955). The disposition toward originality. The Journal of Abnormal and Social Psychology, 51(3), p.478.

https://doi.org/10.1037/h0048073

Baumol, W. J. (1996). Entrepreneurship: Productive, unproductive, and destructive. Journal of Business Venturing, 11(1), 3-22. https://doi.org/10.1016/0883-9026(94)00014-x 
Beckman, G. D. (2007). "Adventuring" arts entrepreneurship curricula in higher education: An examination of present efforts, obstacles, and best practices. The Journal of Arts Management, Law, and Society, 37(2), 87-112.

https://doi.org/10.2139/ssrn.937333

Bridgstock, R. (2013). Not a dirty word: Arts entrepreneurship and higher education. Arts and Humanities in Higher Education, 12(2-3), 122-137.

https://doi.org/10.1177/1474022212465725

Brockhaus, R. (1980). Risk Taking Propensity of Entrepreneurs. Academy of Management Journal, 23(3), 509-520.

https://doi.org/10.1177/1474022212465725

Campbell, W. K., Goodie, A. S. and Foster, J. D. (2004). Narcissism, Confidence, and Risk Attitude. Journal of Behavioral Decision Making, 17(4), 297-311. Cardon, M. S. and Kirk, C. P. (2015). Entrepreneurial passion as mediator of the self-efficacy to persistence relationship. Entrepreneurship Theory and Practice,39(5), 1027-1050.

https://doi.org/10.1002/bdm.475

Carland Jr, J. W., Carland, J. A. C. and Carland III, J. W. T. (1995). Self-actualization: The zenith of entrepreneurship. Journal of Small Business Strategy, 6(1), 53-66.

Carr, A., 2011. Positive psychology: The science of happiness and human strengths. Routledge.

https://doi.org/10.4324/9780203156629

Collins, M. A. and Amabile, T. M. (1999). Motivation and creativity. Handbook of Creativity, 297, 1051-1057.

https://doi.org/10.1017/cbo9780511807916.017

Coulson, S. (2012). Collaborating in a competitive world: Musicians' working lives and understandings of entrepreneurship. Work, Employment and Society, 26, 246-261. https://doi.org/10.1177/0950017011432919

Cowen, T. and Tabarrok, A. (2000). An economic theory of avant-garde and popular art, or high and low culture. Southern Economic Journal, 67(2), 232-253.

https://doi.org/10.2307/1061469

Cross, P. G., Cattell, R. B., and Butcher, H. J. (1967). The personality pattern of creative artists. British Journal of Educational Psychology, 37(3), 292-299.

https://doi.org/10.1111/j.2044-8279.1967.tb01944.x

Csikszentmihalyi, M. and Getzels, J.W. (1973). The personality of young artists: An empirical and theoretical exploration. British Journal of Psychology 64(1), 91- 104. https://doi.org/10.1007/978-94-017-9085-7_2

Daum, K. (2005). Entrepreneurs: The artists of the business world. Journal of Business Strategy, 26(5), 53-57. https://doi.org/10.1108/02756660510700546 
Dohmen, T., Huffman, D., Schupp, J., Falk, A. Sunde, U. and Wagner, G.G. (2011).

Individual risk attitudes: Measurement, determinants and behavioral consequences. Journal of the European Economic Association, 9(3), 522-550.

https://doi.org/10.26481/umaror.2009006

Drevdahl, J.E. and Cattell, R.B. (1958). Personality and creativity in artists and writers.

Journal of Clinical Psychology, 14(2), 107-111

https://doi.org/10.1002/1097-4679(195804)14:2<107::aid-jclp2270140202>3.0.co;2-t

Eikhof, D.R. and Haunschild, A. (2006) Lifestyle meets market: Bohemian entrepreneurs in creative industries. Creativity and Innovation Management, 15(3), 234-241.

https://doi.org/10.1111/j.1467-8691.2006.00392.x

Feist, G.J. (1998). A meta-analysis of personality in scientific and artistic creativity.

Personality and Social Psychology Review, 2(4), 290-309.

https://doi.org/10.1207/s15327957pspr0204 5

Feist, G. J. (1999). The influence of personality on artistic and scientific creativity. Handbook of Creativity, 273-296.

https://doi.org/10.1017/cbo9780511807916.016

Frank, R.H., Cook, P.J. (1996). The winner-take-all society, Penguin

Gartner, W. B. (1989). Some suggestions for research on entrepreneurial traits and characteristics. Entrepreneurship Theory and Practice, 4(1), 27-37.

https://doi.org/10.1177/104225878901400103

Germak, A.J. and Robinson, J.A. (2014). Exploring the Motivation of Nascent Social Entrepreneurs. Journal of Social Entrepreneurship, 5(1), 5-21.

https://doi.org/10.1080/19420676.2013.820781

Götz, K. O. and Götz, K. (1979). Personality characteristics of professional artists. Perceptual and Motor Skills, 49(1), 327-334.

https://doi.org/10.2466/pms.1979.49.1.327

Grant, A.M. and Berry, J.W. (2011). The Necessity of Others is The Mother of Invention: Intrinsic and Prosocial Motivations, Perspective Taking, and Creativity. Academy of Management Journal, 54(1) 73-96.

https://doi.org/10.5465/amj.2011.59215085

Harris, B. (2011). Sacred Selfishness: guide to living a life of substance. New World Library.

Heunks, F. (1998). Innovation, creativity and success. Small Business Economics, 10, 263272.

https://doi.org/10.1023/A:1007968217565

Honos-Webb, L. (2010). The gift of ADHD: How to transform your child's problems into strengths. New Harbinger Publications. 
Kemp, A. E. (1996). The Musical Temperament: Psychology and Personality of Musicians. Oxford University Press.

https://doi.org/10.1093/acprof:oso/9780198523628.001.0001

Kenny, D.T., Davis, P. and Oates, J. (2004). Music performance anxiety and occupational stress amongst opera chorus artists and their relationship with state and trait anxiety and perfectionism. Journal of Anxiety Disorders, 18(6), 757-777.

https://doi.org/10.1016/j.janxdis.2003.09.004

Kessler, R.C., Adler, L., Ames, M., Demler, O., Faraone, S., Hiripi, E.V.A., Howes, M.J., Jin, R., Secnik, K., Spencer, T. and Ustun, T.B. (2005). The World Health Organization Adult ADHD Self-Report Scale (ASRS): A short screening scale for use in the general population. Psychological Medicine, 35(2), 245-256.

https://doi.org/10.1017/s0033291704002892

Khan, S. A., Tang, J. and Joshi, K. (2014). Disengagement of nascent entrepreneurs from the start-up process. Journal of Small Business Management, 52(1), 39-58.

https://doi.org/10.1111/jsbm.12032

Koellinger, P., Minniti, M. and Schade, C. (2007). "I think I can, I think I can":

Overconfidence and entrepreneurial behavior. Journal of Economic Psychology, 28(4), 502527.

https://doi.org/10.1016/j.joep.2006.11.002

Krueger Jr, N. and Dickson, P.R. (1994). How believing in ourselves increases risk taking: Perceived self-efficacy and opportunity recognition. Decision Sciences, 25(3), 3 85-400. https://doi.org/10.1111/j.1540-5915.1994.tb01849.x

Lasky, A.K., Weisner, T.S., Jensen, P.S., Hinshaw, S.P., Hechtman, L., Arnold, L.E., Murray, D., Swanson, J.M. (2016). ADHD in context: Young adults' reports of the impact of occupational environment on the manifestation of ADHD, Social Science Medicine, 161, 160-168.

https://doi.org/10.1016/j.socscimed.2016.06.003

Lejuez, C.W., Read, J.P., Kahler, C.W., Richards, J.B., Ramsey, S.E., Stuart, G.L., Strong, D.R. and Brown, R.A. (2002). Evaluation of a behavioral measure of risk taking: The Balloon Analogue Risk Task (BART). Journal of Experimental Psychology: Applied, 8(2), 75.

https://doi.org/10.1037/1076-898x.8.2.75

Lerner, D., Verheul, I. and Thurik, R. (2019). Entrepreneurship and attention deficit/hyperactivity disorder: A large-scale study involving the clinical condition of ADHD. Small Business Economics, 53(2), 381-392.

https://doi.org/10.1007/s11187-018-0061-1

Maslow, A.H. (1943). A theory of human motivation. Psychological Review, 50(4), 370-396. https://doi.org/10.1037/h0054346 
McClelland, D.C. (1987) Characteristics of successful entrepreneurs. The Journal of Creative Behavior, 21(3), 219-233.

https://doi.org/10.1002/j.2162-6057.1987.tb00479.x

McClintock, C. G. and Allison, S. T. (1989). Social value orientation and helping behavior. Journal of Applied Social Psychology, 19(4), 353-362.

https://doi.org/10.1111/j.1559-1816.1989.tb00060.x

McCrae, R.R. (1987). Creativity, divergent thinking, and openness to experience. Journal of Personality and Social Psychology, 52(6), 1258.

https://doi.org/10.1037/0022-3514.52.6.1258

Messick, D. M. and McClintock, C. G. (1968). Motivational bases of choice in experimental games. Journal of Experimental Social Psychology, 4(1), 1-25.

https://doi.org/10.1016/0022-1031(68)90046-2

Mor, S., Day, H.I., Flett, G.L. and Hewitt, P.L. (1995). Perfectionism, control, and components of performance anxiety in professional artists. Cognitive Therapy and Research, 19(2), 207-225.

https://doi.org/10.1007/bf02229695

Nicholls, J.G. (1984). Achievement motivation: Conceptions of ability, subjective experience, task choice, and performance. Psychological Review, 91(3), 328.

https://doi.org/10.1037/0033-295x.91.3.328

Pedroni, A., Frey, R., Bruhin, A., Dutilh, G., Hertwig, R., and Rieskamp, J. (2017). The risk elicitation puzzle. Nature Human Behaviour, 1, 803-809.

https://doi.org/10.1038/s41562-017-0219-x

Pekkala Kerr, S., Kerr, W.R. and Xu, T. (2018). Personality Traits of Entrepreneurs: A Review of Recent Literature. Foundations and Trends in Entrepreneurship, 14(3), 279-356. https://doi.org/10.3386/w24097

Pletzer, J. L., Balliet, D., Joireman, J., Kuhlman, D. M., Voelpel, S. C. and Van Lange, P. A. (2018). Social value orientation, expectations, and cooperation in social dilemmas: A metaanalysis. European Journal of Personality, 32(1), 62-83.

https://doi.org/10.1002/per.2139

Plucker, J. A. and Renzulli, J. S. (1999). Psychometric approaches to the study of human creativity. Handbook of creativity, 35, 61.

https://doi.org/10.1017/cbo9780511807916.005

Poorsoltan, K. (2012). Artists as entrepreneurs. International Journal of Entrepreneurship, 16, 77.

Poschke, M. (2013). Who becomes an entrepreneur? Labor market prospects and occupational choice. Journal of Economic Dynamics and Control, 37(3), 693- 710. https://doi.org/10.1016/j.jedc.2012.11.003

Rank, O. (1932). Art and Artist: Creative Urge and Personality Development. Tudor. 
Rauch, A. (2014). Predictions of entrepreneurial behavior: A personality approach. In Handbook of Research on Small Business and Entrepreneurship. Edited by E. Chell and M. https://doi.org/10.4337/9781849809245.00018

Rotter, J. B. (1966). Generalized expectancies for internal versus external control of reinforcement. Psychological monographs: General and applied, 80(1), 1-28.

https://doi.org/10.1037/h0092976

Ryan, R.M. and Deci, E.L. (2000). Intrinsic and extrinsic motivations: Classic definitions and new directions. Contemporary Educational Psychology, 25(1), 54-67.

https://doi.org/10.1006/ceps.1999.1020

Scherer, R. F., Adams, J. S., Carley, S. S. and Wiebe, F. A. (1989). Role model performance: Effects on development of entrepreneurial career preference. Entrepreneurship Theory and Practice, 13(3), 53-71. https://doi.org/10.1177/104225878901300306

Shaver, K. and Scott, L. R. (1991). Person, Process, Choice: The Psychology of New Venture Creation. Entrepreneurship Theory and Practice, 16, 23-45.

https://doi.org/10.1177/104225879201600204

Stewart, W. and Roth, P. (2001). Risk propensity differences between entrepreneurs and managers: A meta-analytic review. Journal of Applied Psychology, 86(1), 145-153.

https://doi.org/10.1037/0021-9010.86.1.145

Swedberg, R. (2006). The cultural entrepreneur and the creative industries: beginning in Vienna. Journal of Cultural Economics, 30(4), 243-261.

https://doi.org/10.1007/s10824-006-9016-5

Throsby, D. and Zednik, A. (2011). Multiple job-holding and artistic careers: Some empirical evidence. Cultural trends, 20(1), 9-24.

https://doi.org/10.1080/09548963.2011.540809

Timmons, J. (1989). The Entrepreneurial Mind. Brick House.

Townsend, D. M., Busenitz, L. W. and Arthurs, J. D. (2010). To start or not to start: Outcome and ability expectations in the decision to start a new venture. Journal of Business Venturing, 25(2), 192-202.

https://doi.org/10.1016/j.jbusvent.2008.05.003

Van de Vyver, J. and Abrams, D. (2018). The arts as a catalyst for human prosociality and cooperation. Social Psychological and Personality Science, 9(6), 664-674.

https://doi.org/10.1177/1948550617720275

Van Lange, P. A., Bekkers, R., Schuyt, T. N. and Vugt, M. V. (2007). From games to giving: Social value orientation predicts donations to noble causes. Basic and Applied Social Psychology, 29(4), 375-384. https://doi.org/10.1080/01973530701665223 
VandeWalle, D. (1997). Development and validation of a work domain goal orientation instrument. Educational and psychological measurement, 57(6), 995- 1015.

https://doi.org/10.1177/0013164497057006009

Verheul, I., Block, J., Burmeister-Lamp, K., Thurik, R., Tiemeier, H. and Turturea, R. (2015). ADHD-like behavior and entrepreneurial intentions. Small Business Economics, 45(1), 85-101.

https://doi.org/10.1007/s11187-015-9642-4

Ward, T.B. (2004). Cognition, creativity, and entrepreneurship. Journal of Business Venturing, 19, 173-188.

https://doi.org/10.1016/s0883-9026(03)00005-3

Wiklund, J., Yu, W. and Patzelt, H. (2018). Impulsivity and entrepreneurial action. Academy of Management Perspective, 33(3), 379-403.

https://doi.org/10.5465/ambpp.2016.13945abstract

Woronkowicz, J. and Noonan, D.S. (2019). Who goes freelance? The determinants of selfemployment for artists. Entrepreneurship Theory and Practice, 43(4), 651-672.

https://doi.org/10.1177/1042258717728067

Yang, X. and Zhu, L. (2016). Ambiguity vs risk: An experimental study of overconfidence, gender and trading activity. Journal of Behavioral and Experimental Finance, 9, 125-131. https://doi.org/10.1016/j.jbef.2016.01.003

Zhao, H. and Seibert, S.E. (2006). The big five personality dimensions and entrepreneurial status: A meta-analytical review. Journal of Applied Psychology, 91, 259-271.

https://doi.org/10.1037/0021-9010.91.2.259

Zhou, J. and Shalley, C. E. (2003). Research on employee creativity: A critical review and directions for future research. In Research in personnel and human resources management, pp. 165-217. Emerald.

https://doi.org/10.1016/s0742-7301(03)22004-1 
Table 1 Summary of psychological dimensions, measures, hypotheses and results.

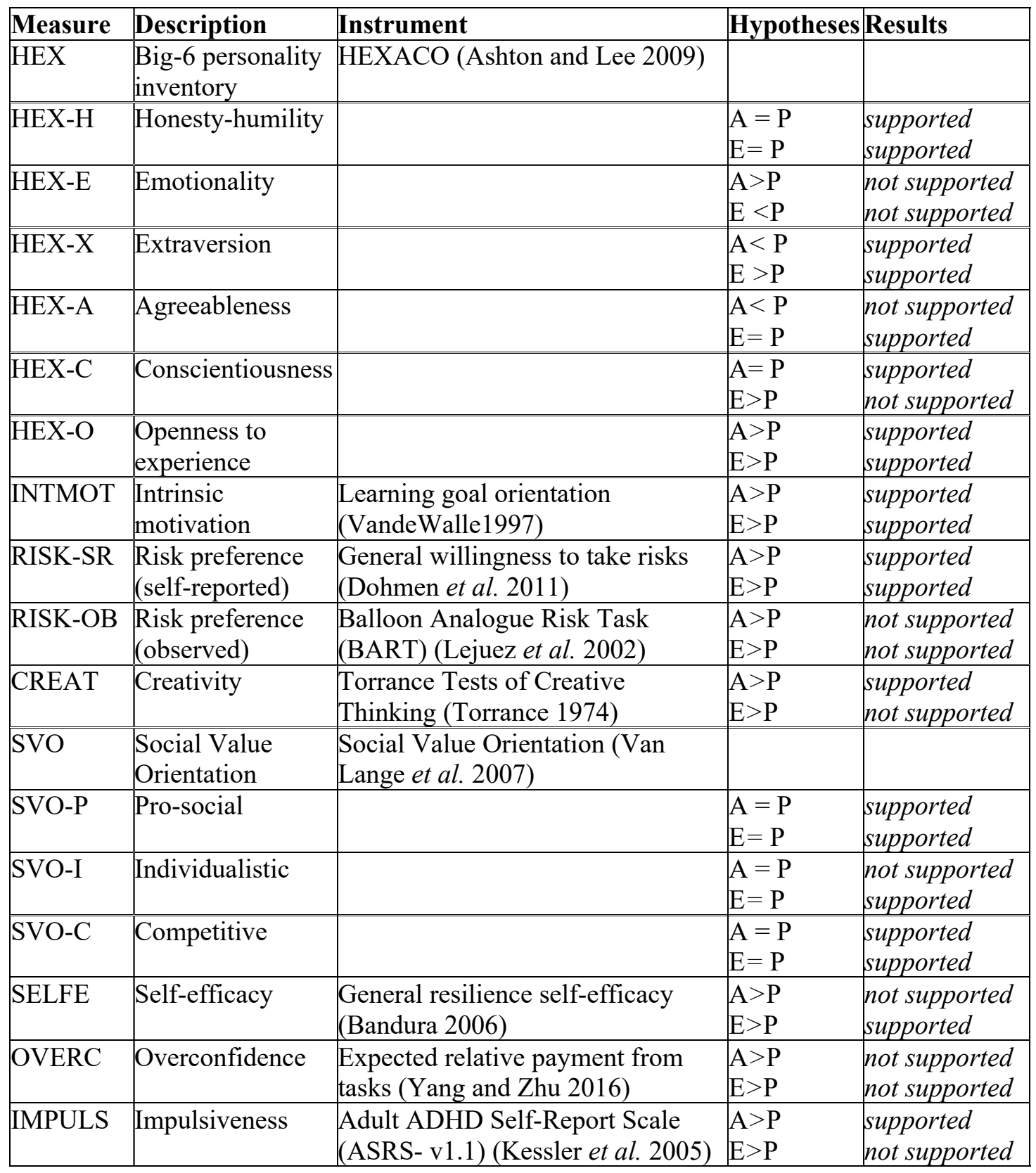


Table 2 Participant demographics by group.

\begin{tabular}{|l|l|l|l|l|}
\hline Group: & Artists & Entrepreneurs & Professionals & All \\
\hline$N$ & 93 & 76 & 47 & 216 \\
Average age & 35.2 & 35.3 & 38.9 & 36 \\
(years) & & & & \\
Female & $58.2 \%$ & $34.2 \%$ & $61.7 \%$ & $50.5 \%$ \\
High School & $6.4 \%$ & $6.6 \%$ & $4.2 \%$ & $6.0 \%$ \\
Diploma & $18.3 \%$ & $10.5 \%$ & $17.0 \%$ & $15.3 \%$ \\
Bachelors & $48.4 \%$ & $43.4 \%$ & $42.6 \%$ & $45.4 \%$ \\
Postgrad & $26.9 \%$ & $39.5 \%$ & $36.2 \%$ & $33.3 \%$ \\
Native English & $90.3 \%$ & $80.0 \%$ & $76.6 \%$ & $83.7 \%$ \\
\hline
\end{tabular}


Table 3 Left panel: Average participant scores for psychological measures by group: artists (A), entrepreneurs (E) and professionals (P). Right Panel: Group difference and associated Scheff'e post-hoc test results. $* p<0.1, * * p<0.05, * * * p$ $<0.01$. All tests based on analysis of variance bar SVO, where $\chi^{2}$-tests were used.

\begin{tabular}{|l|l|l|l|l|l|l|l||}
\hline & \multicolumn{3}{|l}{ Group } & Difference & \multicolumn{3}{|l|}{ Scheffé post-hoc } \\
\hline & $\mathrm{A}$ & $\mathrm{E}$ & $\mathrm{P}$ & & $\mathrm{A}-\mathrm{P}$ & $\mathrm{E}-\mathrm{P}$ & $\mathrm{A}-\mathrm{E}$ \\
\hline HEX-H & 3.61 & 3.64 & 3.73 & 0.59 & -0.12 & -0.09 & -0.03 \\
HEX-E & 3.29 & 2.92 & 3.07 & $6.04 * * *$ & 0.22 & -0.15 & $0.37 * * *$ \\
HEX-X & 3.43 & 3.88 & 3.66 & $12.50 * * *$ & $-0.23 *$ & 0.22 & $-0.45 * * *$ \\
HEX-A & 3.24 & 3.32 & 3.31 & 0.38 & -0.07 & 0.01 & -0.08 \\
HEX-C & 3.81 & 3.73 & 3.80 & 0.53 & 0.01 & -0.07 & 0.08 \\
HEX-O & 4.40 & 4.02 & 3.67 & $27.18 * * *$ & $0.73 * * *$ & $0.35 * * *$ & $0.38 * * *$ \\
\hline INTMOT & 4.54 & 4.38 & 4.20 & $5.15 * * *$ & $0.34 * * *$ & 0.18 & 0.16 \\
\hline RISK-SR & 6.75 & 6.86 & 5.66 & $5.97 * * *$ & $1.09 * *$ & $1.20 * * *$ & -0.11 \\
RISK-OB & 43.01 & 50.42 & 44.47 & $2.77 *$ & -1.46 & 5.95 & $-7.41 *$ \\
\hline CREAT & 17.06 & 14.63 & 13.57 & $12.33 * * *$ & $3.49 * * *$ & 1.06 & $2.43 * * *$ \\
\hline SVO-P $(\%)$ & 83.9 & 61.8 & 74.5 & $10.57 * * *$ & 9.4 & -12.7 & $22.1 * * *$ \\
SVO-I (\%) & 4.3 & 22.4 & 17.0 & $12.41 * * *$ & $-12.7 * *$ & 5.4 & $-18.1 * * *$ \\
SVO-C (\%) & 0.0 & 3.9 & 2.1 & 3.61 & -2.1 & 1.8 & $-3.9 *$ \\
\hline SELFE & 6.59 & 7.57 & 6.65 & $8.83 * * *$ & -0.06 & $0.92 * *$ & $-0.98 * * *$ \\
\hline OVERC & 4.90 & 5.51 & 5.02 & 1.89 & -0.12 & 0.49 & -0.61 \\
\hline ADHD & 2.99 & 2.87 & 2.71 & $4.39 * *$ & $0.28 * *$ & 0.16 & 0.12 \\
\hline
\end{tabular}


Table 4 Pearson Product-Moment Intercorrelations between psychological measures. $* p<0.1, * * p<0.05, * * * p<0.01$.

\begin{tabular}{|c|c|c|c|c|c|c|c|c|c|c|c|c|}
\hline \multirow{2}{*}{\multicolumn{2}{|c|}{\begin{tabular}{|l|l|} 
& RISK-SR \\
ISK-OB & $0.162 *$ \\
\end{tabular}}} & \multirow{2}{*}{\multicolumn{2}{|c|}{\begin{tabular}{l|l|} 
RISK-OB & CREAT \\
\end{tabular}}} & \multirow[t]{2}{*}{ SELFE } & \multirow[t]{2}{*}{ INTMOT } & \multirow[t]{2}{*}{ ADHD } & \multicolumn{2}{|c|}{ OVERCHEX-H } & \multirow[t]{2}{*}{ HEX-E } & \multicolumn{3}{|c|}{\begin{tabular}{l|l|l} 
HEX-X & HEX-A & HEX-C \\
\end{tabular}} \\
\hline & & & & & & & & & & & & \\
\hline CREAT & 0.040 & 0.018 & & & & & & & & & & \\
\hline SELFE & $0.338 * * *$ & $0.134 *$ & -0.131 & & & & & & & & & \\
\hline INTMOT & $0.328 * * *$ & -0.037 & 0.020 & $0.238 * * *$ & & & & & & & & \\
\hline ADHD & 0.014 & 0.087 & $0.167 *$ & $-0.241 * * *$ & *-0.007 & & & & & & & \\
\hline OVERC & 0.080 & -0.108 & $0.164 *$ & $0.134 *$ & 0.036 & 0.011 & & & & & & \\
\hline HEX-H & 0.073 & 0.098 & -0.068 & $0.249 * * *$ & $0.140 *$ & $-0.236 * * *$ & $*-0.031$ & & & & & \\
\hline HEX-E & $-0.290 * *$ & $*-0.023$ & 0.082 & $-0.524 * * *$ & * 0.008 & $0.218 * *$ & $-0.146 *$ & $-0.160 *$ & & & & \\
\hline HEX-X & $0.173 *$ & 0.003 & -0.033 & $0.471 * * *$ & $0.160 *$ & $-0.162 *$ & $0.138 *$ & 0.040 & $-0.266 * * *$ & & & \\
\hline HEX-A & $0.150 *$ & 0.025 & $-0.138 *$ & $0.393 * * *$ & $0.242 * * *$ & $-0.235 * * *$ & *-0.071 & $0.368 * * *$ & $-0.302 * * *$ & $* 0.212 * *$ & & \\
\hline HEX-C & -0.038 & -0.071 & -0.062 & $0.149 *$ & $0.175 *$ & $-0.346 * * *$ & * 0.086 & $0.144 *$ & 0.037 & 0.007 & $0.187 * *$ & \\
\hline HEX-O & $0.204 * *$ & -0.025 & $0.234 * * *$ & 0.099 & $0.222 * *$ & 0.075 & -0.000 & 0.132 & 0.123 & 0.080 & 0.064 & 0.059 \\
\hline
\end{tabular}


Table 5 Regression Results for participant scores for personality (ordinary least squares) and social value orientation (logit). The three horizontal panels estimate the same models with a different group as the benchmark. Standardized beta coefficients with robust standard errors in parentheses. ${ }^{*} p<0.1,{ }^{* *} p<0.05,{ }^{* * *} p<0.01$.

\begin{tabular}{|c|c|c|c|c|c|c|c|c|}
\hline Model: & (1) & $(2)$ & (3) & (4) & $(5)$ & (6) & (7) & $(8)$ \\
\hline DV: & HEX-H & HEX-E & HEX-X & HEX-A & HEX-C & HEX-O & SVO-I & SVO-P \\
\hline Artist & $\begin{array}{l}-0.063 \\
(0.117)\end{array}$ & $\begin{array}{c}0.098 \\
(0.119)\end{array}$ & $\begin{array}{c}-0.204^{* * *} \\
(0.110)\end{array}$ & $\begin{array}{c}0.001 \\
(0.117)\end{array}$ & $\begin{array}{c}0.023 \\
(0.0895)\end{array}$ & $\begin{array}{c}0.539^{* * *} \\
(0.114)\end{array}$ & $\begin{array}{c}-2.223^{* *} \\
(0.680)\end{array}$ & $\begin{array}{c}0.830 \\
(0.460)\end{array}$ \\
\hline Entrepreneur & $\begin{array}{c}-0.041 \\
(0.116)\end{array}$ & $\begin{array}{l}-0.081 \\
(0.129)\end{array}$ & $\begin{array}{l}0.188^{* *} \\
(0.100)\end{array}$ & $\begin{array}{c}0.029 \\
(0.117)\end{array}$ & $\begin{array}{c}-0.061 \\
(0.0988)\end{array}$ & $\begin{array}{c}0.298^{* * * *} \\
(0.127)\end{array}$ & $\begin{array}{c}0.815 \\
(0.495)\end{array}$ & $\begin{array}{c}-0.798 \\
(0.453)\end{array}$ \\
\hline Age & $\begin{array}{c}0.183^{* *} \\
(0.00482)\end{array}$ & $\begin{array}{l}-0.199^{* * *} \\
(0.00393)\end{array}$ & $\begin{array}{c}-0.022 \\
(0.00364)\end{array}$ & $\begin{array}{l}0.181^{* * *} \\
(0.00397)\end{array}$ & $\begin{array}{c}0.040 \\
(0.00385)\end{array}$ & $\begin{array}{c}0.030 \\
(0.00392)\end{array}$ & $\begin{array}{c}0.712 \\
(0.0211)\end{array}$ & $\begin{array}{c}0.583 \\
(0.0192)\end{array}$ \\
\hline Education & $\begin{array}{l}-0.075 \\
(0.0577)\end{array}$ & $\begin{array}{c}0.039 \\
(0.0559)\end{array}$ & $\begin{array}{c}0.023 \\
(0.0468)\end{array}$ & $\begin{array}{c}-0.122 \\
(0.0599)\end{array}$ & $\begin{array}{c}-0.072 \\
(0.0432)\end{array}$ & $\begin{array}{l}-0.084 \\
(0.0455)\end{array}$ & $\begin{array}{c}-0.263 \\
(0.228)\end{array}$ & $\begin{array}{l}-0.208 \\
(0.201)\end{array}$ \\
\hline Female & $\begin{array}{c}0.018 \\
(0.0743)\end{array}$ & $\begin{array}{l}0.228^{* * *} \\
(0.0803)\end{array}$ & $\begin{array}{c}0.103^{*} \\
(0.0624)\end{array}$ & $\begin{array}{c}-0.080 \\
(0.0716)\end{array}$ & $\begin{array}{c}0.011 \\
(0.0756)\end{array}$ & $\begin{array}{l}0.151^{* * *} \\
(0.0602)\end{array}$ & $\begin{array}{c}0.865 \\
(0.325)\end{array}$ & $\begin{array}{c}-0.969^{* *} \\
(0.287)\end{array}$ \\
\hline English & $\begin{array}{c}-0.062 \\
(0.110)\end{array}$ & $\begin{array}{c}-0.021 \\
(0.128)\end{array}$ & $\begin{array}{c}0.028 \\
(0.109)\end{array}$ & $\begin{array}{l}-0.124^{*} \\
(0.115)\end{array}$ & $\begin{array}{c}-0.102 \\
(0.0904)\end{array}$ & $\begin{array}{c}0.062 \\
(0.119)\end{array}$ & $\begin{array}{c}-0.287 \\
(0.577)\end{array}$ & $\begin{array}{c}0.313 \\
(0.413)\end{array}$ \\
\hline Artist & $\begin{array}{l}-0.020 \\
(0.103)\end{array}$ & $\begin{array}{l}0.182^{* *} \\
(0.109)\end{array}$ & $\begin{array}{l}-0.399^{* * *} \\
(0.0931)\end{array}$ & $\begin{array}{l}-0.029 \\
(0.112)\end{array}$ & $\begin{array}{c}0.087 \\
(0.0846)\end{array}$ & $\begin{array}{l}0.230^{* * *} \\
(0.0828)\end{array}$ & $\begin{array}{r}-3.069^{* * *} \\
(0.627)\end{array}$ & $\begin{array}{l}1.659^{* * *} \\
(0.419)\end{array}$ \\
\hline Professional & $\begin{array}{c}0.036 \\
(0.116)\end{array}$ & $\begin{array}{c}0.070 \\
(0.129)\end{array}$ & $\begin{array}{c}-0.163^{* *} \\
(0.100)\end{array}$ & $\begin{array}{c}-0.025 \\
(0.117)\end{array}$ & $\begin{array}{c}0.053 \\
(0.0988)\end{array}$ & $\begin{array}{c}-0.258^{* * *} \\
(0.127)\end{array}$ & $\begin{array}{l}-0.706 \\
(0.495)\end{array}$ & $\begin{array}{c}0.692 \\
(0.453)\end{array}$ \\
\hline Age & $\begin{array}{c}0.183^{* *} \\
(0.00482)\end{array}$ & $\begin{array}{l}-0.199^{* * *} \\
(0.00393)\end{array}$ & $\begin{array}{c}-0.022 \\
(0.00364)\end{array}$ & $\begin{array}{l}0.181 * * \\
(0.00397)\end{array}$ & $\begin{array}{c}0.040 \\
(0.00385)\end{array}$ & $\begin{array}{c}0.030 \\
(0.00392)\end{array}$ & $\begin{array}{c}0.712 \\
(0.0211)\end{array}$ & $\begin{array}{c}0.583 \\
(0.0192)\end{array}$ \\
\hline Education & $\begin{array}{c}-0.075 \\
(0.0577)\end{array}$ & $\begin{array}{c}0.039 \\
(0.0559)\end{array}$ & $\begin{array}{c}0.023 \\
(0.0468)\end{array}$ & $\begin{array}{c}-0.122 \\
(0.0599)\end{array}$ & $\begin{array}{c}-0.072 \\
(0.0432)\end{array}$ & $\begin{array}{l}-0.084 \\
(0.0455)\end{array}$ & $\begin{array}{l}-0.263 \\
(0.228)\end{array}$ & $\begin{array}{l}-0.208 \\
(0.201)\end{array}$ \\
\hline Female & $\begin{array}{c}0.018 \\
(0.0743)\end{array}$ & $\begin{array}{l}0.228^{* * *} \\
(0.0803)\end{array}$ & $\begin{array}{c}0.103^{*} \\
(0.0624)\end{array}$ & $\begin{array}{c}-0.080 \\
(0.0716)\end{array}$ & $\begin{array}{c}0.011 \\
(0.0756)\end{array}$ & $\begin{array}{l}0.151^{* * *} \\
(0.0602)\end{array}$ & $\begin{array}{c}0.865 \\
(0.325)\end{array}$ & $\begin{array}{c}-0.969^{* *} \\
(0.287)\end{array}$ \\
\hline English & $\begin{array}{c}-0.062 \\
(0.110)\end{array}$ & $\begin{array}{c}-0.021 \\
(0.128)\end{array}$ & $\begin{array}{c}0.028 \\
(0.109)\end{array}$ & $\begin{array}{l}-0.124^{*} \\
(0.115)\end{array}$ & $\begin{array}{c}-0.102 \\
(0.0904)\end{array}$ & $\begin{array}{c}0.062 \\
(0.119)\end{array}$ & $\begin{array}{c}-0.287 \\
(0.577)\end{array}$ & $\begin{array}{c}0.313 \\
(0.413)\end{array}$ \\
\hline Entrepreneur & $\begin{array}{c}0.019 \\
(0.103)\end{array}$ & $\begin{array}{c}-0.176^{* *} \\
(0.109)\end{array}$ & $\begin{array}{l}0.384^{* * *} \\
(0.0931)\end{array}$ & $\begin{array}{c}0.028 \\
(0.112)\end{array}$ & $\begin{array}{c}-0.084 \\
(0.0846)\end{array}$ & $\begin{array}{l}-0.221^{* * *} \\
(0.0828)\end{array}$ & $\begin{array}{l}2.953^{* * *} \\
(0.627)\end{array}$ & $\begin{array}{c}-1.596^{* * *} \\
(0.419)\end{array}$ \\
\hline Professional & $\begin{array}{c}0.052 \\
(0.117)\end{array}$ & $\begin{array}{c}-0.082 \\
(0.119)\end{array}$ & $\begin{array}{l}0.170^{* *} \\
(0.110)\end{array}$ & $\begin{array}{l}-0.001 \\
(0.117)\end{array}$ & $\begin{array}{c}-0.019 \\
(0.0895)\end{array}$ & $\begin{array}{c}-0.450^{* * *} \\
(0.114)\end{array}$ & $\begin{array}{l}1.854^{* *} \\
(0.680)\end{array}$ & $\begin{array}{c}-0.693 \\
(0.460)\end{array}$ \\
\hline Age & $\begin{array}{c}0.183^{* *} \\
(0.00482)\end{array}$ & $\begin{array}{l}-0.199^{* * *} \\
(0.00393)\end{array}$ & $\begin{array}{c}-0.022 \\
(0.00364)\end{array}$ & $\begin{array}{l}0.181^{* * *} \\
(0.00397)\end{array}$ & $\begin{array}{c}0.040 \\
(0.00385)\end{array}$ & $\begin{array}{c}0.030 \\
(0.00392)\end{array}$ & $\begin{array}{c}0.712 \\
(0.0211)\end{array}$ & $\begin{array}{c}0.583 \\
(0.0192)\end{array}$ \\
\hline Education & $\begin{array}{c}-0.075 \\
(0.0577)\end{array}$ & $\begin{array}{c}0.039 \\
(0.0559)\end{array}$ & $\begin{array}{c}0.023 \\
(0.0468)\end{array}$ & $\begin{array}{l}-0.122 \\
(0.0599)\end{array}$ & $\begin{array}{c}-0.072 \\
(0.0432)\end{array}$ & $\begin{array}{l}-0.084 \\
(0.0455)\end{array}$ & $\begin{array}{l}-0.263 \\
(0.228)\end{array}$ & $\begin{array}{l}-0.208 \\
(0.201)\end{array}$ \\
\hline Female & $\begin{array}{c}0.018 \\
(0.0743)\end{array}$ & $\begin{array}{l}0.228^{* * *} \\
(0.0803)\end{array}$ & $\begin{array}{c}0.103^{*} \\
(0.0624)\end{array}$ & $\begin{array}{l}-0.080 \\
(0.0716)\end{array}$ & $\begin{array}{c}0.011 \\
(0.0756)\end{array}$ & $\begin{array}{l}0.151^{* * *} \\
(0.0602)\end{array}$ & $\begin{array}{c}0.865 \\
(0.325)\end{array}$ & $\begin{array}{c}-0.969^{* *} \\
(0.287)\end{array}$ \\
\hline English & $\begin{array}{l}-0.062 \\
(0.110)\end{array}$ & $\begin{array}{l}-0.021 \\
(0.128)\end{array}$ & $\begin{array}{c}0.028 \\
(0.109)\end{array}$ & $\begin{array}{l}-0.124^{*} \\
(0.115)\end{array}$ & $\begin{array}{c}-0.102 \\
(0.0904)\end{array}$ & $\begin{array}{c}0.062 \\
(0.119)\end{array}$ & $\begin{array}{c}-0.287 \\
(0.577)\end{array}$ & $\begin{array}{c}0.313 \\
(0.413)\end{array}$ \\
\hline$N$ & 215 & 215 & 215 & 215 & 215 & 215 & 215 & 215 \\
\hline $\begin{array}{l}R^{2} \\
\chi^{2}\end{array}$ & 0.035 & 0.144 & 0.114 & 0.049 & 0.017 & 0.235 & 15.348 & 16.496 \\
\hline
\end{tabular}


Table 6 Ordinary least squares regression results for participant scores for psychological measures. The three horizontal panels estimate the same models with a different group as the benchmark. Standardized beta coefficients with robust standard errors in parentheses. $* * p<0.1, * * p<0.05, * * * p<0.01$.

\begin{tabular}{|c|c|c|c|c|c|c|c|}
\hline Model: & (1) & (2) & (3) & (4) & (5) & (6) & (7) \\
\hline DV: & RISK-SR & RISK-OB & CREAT & SELFE & INTMOT & ADHD & OVERC \\
\hline Artist & $\begin{array}{c}0.280^{* * *} \\
(0.345)\end{array}$ & $\begin{array}{c}0.022 \\
(3.704)\end{array}$ & $\begin{array}{c}0.323^{* * *} \\
(0.745)\end{array}$ & $\begin{array}{c}0.029 \\
(0.273)\end{array}$ & $\begin{array}{l}0.257^{* * *} \\
(0.112)\end{array}$ & $\begin{array}{l}0.222^{* * *} \\
(0.0901)\end{array}$ & $\begin{array}{c}-0.012 \\
(0.376)\end{array}$ \\
\hline Entrepreneur & $\begin{array}{c}0.319^{* * *} \\
(0.351)\end{array}$ & $\begin{array}{c}0.143 \\
(3.988)\end{array}$ & $\begin{array}{c}0.116 \\
(0.711)\end{array}$ & $\begin{array}{c}0.280^{* * *} \\
(0.252)\end{array}$ & $\begin{array}{c}0.160^{*} \\
(0.115)\end{array}$ & $\begin{array}{c}0.102 \\
(0.0932)\end{array}$ & $\begin{array}{c}0.074 \\
(0.411)\end{array}$ \\
\hline Age & $\begin{array}{c}0.136 \\
(0.0157)\end{array}$ & $\begin{array}{l}0.179^{* *} \\
(0.159)\end{array}$ & $\begin{array}{c}-0.068 \\
(0.0274)\end{array}$ & $\begin{array}{l}0.173^{* *} \\
(0.0101)\end{array}$ & $\begin{array}{c}-0.063 \\
(0.00411)\end{array}$ & $\begin{array}{l}-0.230^{* * *} \\
(0.00331)\end{array}$ & $\begin{array}{c}-0.035 \\
(0.0132)\end{array}$ \\
\hline Education & $\begin{array}{c}0.007 \\
(0.185)\end{array}$ & $\begin{array}{c}-0.008 \\
(1.752)\end{array}$ & $\begin{array}{c}0.036 \\
(0.354)\end{array}$ & $\begin{array}{l}-0.042 \\
(0.136)\end{array}$ & $\begin{array}{c}0.081 \\
(0.0523)\end{array}$ & $\begin{array}{c}0.024 \\
(0.0400)\end{array}$ & $\begin{array}{c}-0.013 \\
(0.171)\end{array}$ \\
\hline Female & $\begin{array}{c}0.080 \\
(0.237)\end{array}$ & $\begin{array}{c}-0.106 \\
(2.432)\end{array}$ & $\begin{array}{c}0.081 \\
(0.506)\end{array}$ & $\begin{array}{l}-0.052 \\
(0.191)\end{array}$ & $\begin{array}{c}0.132^{* *} \\
(0.0673)\end{array}$ & $\begin{array}{c}-0.045 \\
(0.0641)\end{array}$ & $\begin{array}{c}-0.172^{* * *} \\
(0.231)\end{array}$ \\
\hline English & $\begin{array}{l}-0.016 \\
(0.390) \\
\end{array}$ & $\begin{array}{c}-0.073 \\
(3.661) \\
\end{array}$ & $\begin{array}{c}0.225^{* * *} \\
(0.859)\end{array}$ & $\begin{array}{l}-0.087 \\
(0.322) \\
\end{array}$ & $\begin{array}{c}-0.012 \\
(0.131)\end{array}$ & $\begin{array}{c}0.024 \\
(0.0952)\end{array}$ & $\begin{array}{l}-0.010 \\
(0.402) \\
\end{array}$ \\
\hline Artist & $\begin{array}{l}-0.051 \\
(0.345)\end{array}$ & $\begin{array}{c}-0.127 \\
(3.353)\end{array}$ & $\begin{array}{c}0.203^{* *} \\
(0.727)\end{array}$ & $\begin{array}{l}-0.262^{* * *} \\
(0.279)\end{array}$ & $\begin{array}{c}0.091 \\
(0.100)\end{array}$ & $\begin{array}{c}0.116 \\
(0.0916)\end{array}$ & $\begin{array}{c}-0.089 \\
(0.321)\end{array}$ \\
\hline Professional & $\begin{array}{l}-0.277^{* * *} \\
(0.351)\end{array}$ & $\begin{array}{c}-0.124 \\
(3.988)\end{array}$ & $\begin{array}{c}-0.101 \\
(0.711)\end{array}$ & $\begin{array}{l}-0.243^{* * *} \\
(0.252)\end{array}$ & $\begin{array}{l}-0.139^{*} \\
(0.115)\end{array}$ & $\begin{array}{c}-0.088 \\
(0.0932)\end{array}$ & $\begin{array}{c}-0.064 \\
(0.411)\end{array}$ \\
\hline Age & $\begin{array}{c}0.136 \\
(0.0157)\end{array}$ & $\begin{array}{l}0.179^{* *} \\
(0.159)\end{array}$ & $\begin{array}{c}-0.068 \\
(0.0274)\end{array}$ & $\begin{array}{l}0.173^{* *} \\
(0.0101)\end{array}$ & $\begin{array}{c}-0.063 \\
(0.00411)\end{array}$ & $\begin{array}{l}-0.230^{* * *} \\
(0.00331)\end{array}$ & $\begin{array}{c}-0.035 \\
(0.0132)\end{array}$ \\
\hline Education & $\begin{array}{c}0.007 \\
(0.185)\end{array}$ & $\begin{array}{c}-0.008 \\
(1.752)\end{array}$ & $\begin{array}{c}0.036 \\
(0.354)\end{array}$ & $\begin{array}{l}-0.042 \\
(0.136)\end{array}$ & $\begin{array}{c}0.081 \\
(0.0523)\end{array}$ & $\begin{array}{c}0.024 \\
(0.0400)\end{array}$ & $\begin{array}{c}-0.013 \\
(0.171)\end{array}$ \\
\hline Female & $\begin{array}{c}0.080 \\
(0.237)\end{array}$ & $\begin{array}{l}-0.106 \\
(2.432)\end{array}$ & $\begin{array}{c}0.081 \\
(0.506)\end{array}$ & $\begin{array}{l}-0.052 \\
(0.191)\end{array}$ & $\begin{array}{c}0.132^{* *} \\
(0.0673)\end{array}$ & $\begin{array}{c}-0.045 \\
(0.0641)\end{array}$ & $\begin{array}{c}-0.172^{* * * *} \\
(0.231)\end{array}$ \\
\hline English & $\begin{array}{l}-0.016 \\
(0.390)\end{array}$ & $\begin{array}{c}-0.073 \\
(3.661)\end{array}$ & $\begin{array}{l}0.225^{* * *} \\
(0.859)\end{array}$ & $\begin{array}{l}-0.087 \\
(0.322)\end{array}$ & $\begin{array}{l}-0.012 \\
(0.131)\end{array}$ & $\begin{array}{c}0.024 \\
(0.0952)\end{array}$ & $\begin{array}{c}-0.010 \\
(0.402)\end{array}$ \\
\hline Entrepreneur & $\begin{array}{c}0.049 \\
(0.345)\end{array}$ & $\begin{array}{c}0.122 \\
(3.353)\end{array}$ & $\begin{array}{l}-0.195^{* *} \\
(0.727)\end{array}$ & $\begin{array}{c}0.252^{* * *} \\
(0.279)\end{array}$ & $\begin{array}{l}-0.088 \\
(0.100)\end{array}$ & $\begin{array}{c}-0.112 \\
(0.0916)\end{array}$ & $\begin{array}{c}0.086 \\
(0.321)\end{array}$ \\
\hline Professional & $\begin{array}{l}-0.234^{* * *} \\
(0.345)\end{array}$ & $\begin{array}{l}-0.018 \\
(3.704)\end{array}$ & $\begin{array}{l}-0.270^{* * *} \\
(0.745)\end{array}$ & $\begin{array}{l}-0.024 \\
(0.273)\end{array}$ & $\begin{array}{c}-0.215^{* * *} \\
(0.112)\end{array}$ & $\begin{array}{c}-0.185^{* * *} \\
(0.0901)\end{array}$ & $\begin{array}{c}0.010 \\
(0.376)\end{array}$ \\
\hline Age & $\begin{array}{c}0.136 \\
(0.0157)\end{array}$ & $\begin{array}{l}0.179^{* *} \\
(0.159)\end{array}$ & $\begin{array}{c}-0.068 \\
(0.0274)\end{array}$ & $\begin{array}{l}0.173^{* *} \\
(0.0101)\end{array}$ & $\begin{array}{c}-0.063 \\
(0.00411)\end{array}$ & $\begin{array}{l}-0.230^{* * * *} \\
(0.00331)\end{array}$ & $\begin{array}{c}-0.035 \\
(0.0132)\end{array}$ \\
\hline Education & $\begin{array}{c}0.007 \\
(0.185)\end{array}$ & $\begin{array}{c}-0.008 \\
(1.752)\end{array}$ & $\begin{array}{c}0.036 \\
(0.354)\end{array}$ & $\begin{array}{l}-0.042 \\
(0.136)\end{array}$ & $\begin{array}{c}0.081 \\
(0.0523)\end{array}$ & $\begin{array}{c}0.024 \\
(0.0400)\end{array}$ & $\begin{array}{c}-0.013 \\
(0.171)\end{array}$ \\
\hline Female & $\begin{array}{c}0.080 \\
(0.237)\end{array}$ & $\begin{array}{l}-0.106 \\
(2.432)\end{array}$ & $\begin{array}{c}0.081 \\
(0.506)\end{array}$ & $\begin{array}{l}-0.052 \\
(0.191)\end{array}$ & $\begin{array}{c}0.132^{* *} \\
(0.0673)\end{array}$ & $\begin{array}{c}-0.045 \\
(0.0641)\end{array}$ & $\begin{array}{c}-0.172^{* * *} \\
(0.231)\end{array}$ \\
\hline English & $\begin{array}{l}-0.016 \\
(0.390)\end{array}$ & $\begin{array}{c}-0.073 \\
(3.661)\end{array}$ & $\begin{array}{c}0.225^{* * *} \\
(0.859)\end{array}$ & $\begin{array}{l}-0.087 \\
(0.322)\end{array}$ & $\begin{array}{l}-0.012 \\
(0.131)\end{array}$ & $\begin{array}{c}0.024 \\
(0.0952)\end{array}$ & $\begin{array}{l}-0.010 \\
(0.402)\end{array}$ \\
\hline$N$ & 215 & 215 & 215 & 215 & 215 & 215 & 215 \\
\hline$R^{2}$ & 0.077 & 0.067 & 0.153 & 0.106 & 0.073 & 0.089 & 0.047 \\
\hline
\end{tabular}


Fig. 1 Average participant scores by occupational group for the HEXACO personality instrument (top panel), other psychological dimensions (middle) and SVO (bottom). Error bars represent the $95 \%$ confidence interval.

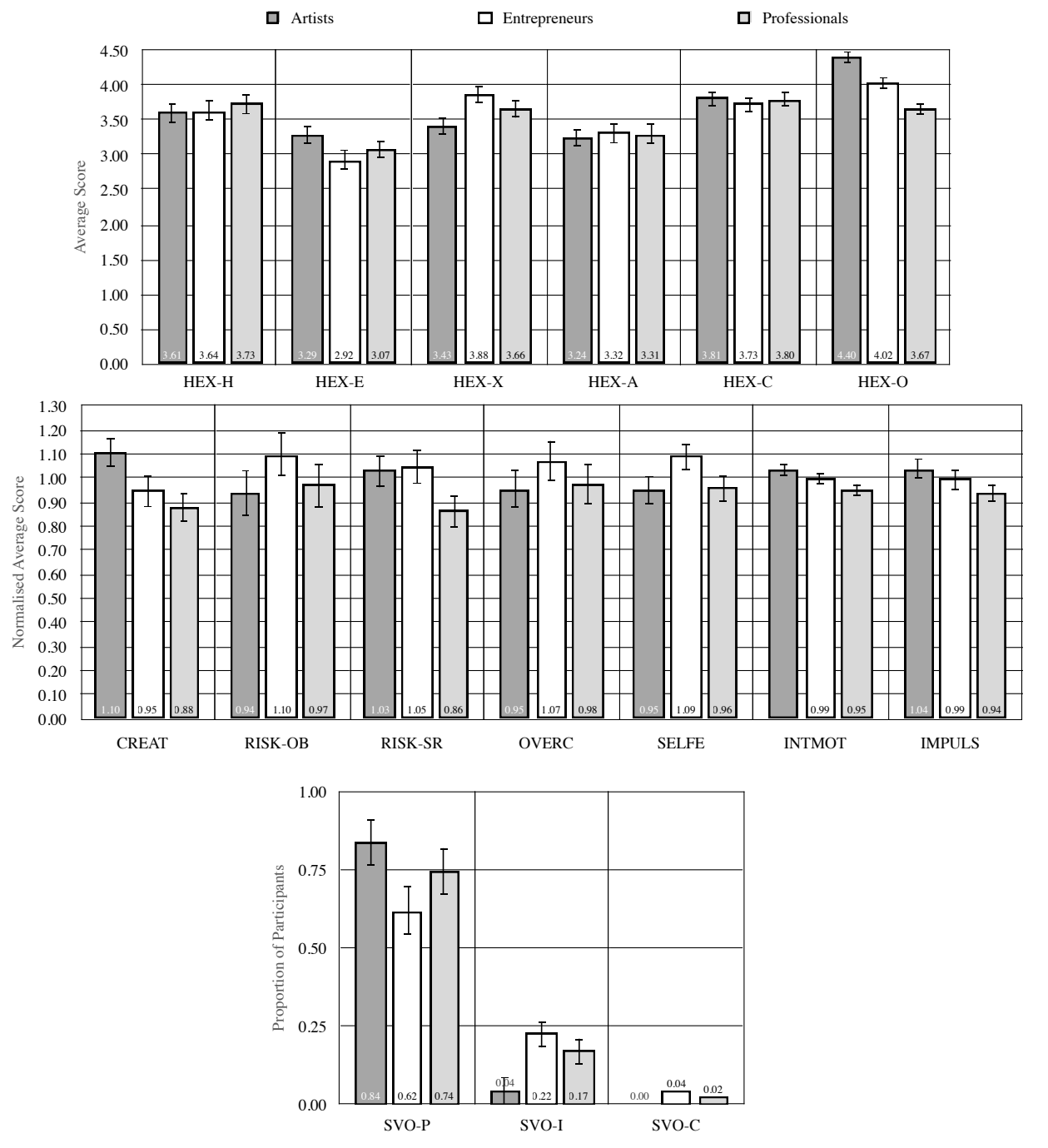

